\title{
Analisis Strategi Komunikasi Pembelajaran Daring Siswa Sekolah Pelita II di Masa Covid-19
}

\author{
Tiffany Gintara ${ }^{1}$, Sinta Paramita ${ }^{2 *}$, Doddy Salman ${ }^{3}$ \\ ${ }^{1}$ Fakultas Ilmu Komunikasi, Universitas Tarumanagara, Jakarta \\ Email: tiffany.915180072@stu.untar.ac.id \\ ${ }^{2}$ Fakultas Ilmu Komunikasi, Universitas Tarumanagara, Jakarta* \\ Email: sintap@fikomuntar.ac.id \\ ${ }^{3}$ Fakultas Ilmu Komunikasi, Universitas Tarumanagara, jakarta \\ Email:doddys@fikom.untar.ac.id
}

Masuk tanggal : 15-12-2021 revisi tanggal :06-01-2022, diterima untuk diterbitkan tanggal : 16-01-2022

\begin{abstract}
As a result of the emergence of the Covid-19 virus that occurred, it had a fairly large impact throughout the world, one of which was Indonesia. The impact of Covid-19 can be felt in various sectors, including in the field of education. Inside, face-to-face learning is shifting to online learning which is one of the logical consequences of today's technological developments. This study aims to analyze the application of communication strategies to Pelita II Elementary School students in online learning during the Covid-19 period, using a qualitative case study method and the model of analysis to see the various problems that are often encountered in Pelita II elementary school during online learning that takes place through the time. Using the theory of diffusion of innovation in analyzing this research problem. The results of this study indicate that the implementation of online learning at SD Pelita II starts from the preparation of the teacher itself by teaching using a strategy that is to create the same understanding and thoughts as the basic form of communication. In addition, the communication process that occurs during online learning is conveyed through the communicator (teacher) to the communicant (student).
\end{abstract}

Keywords: covid-19, e-learning, strategic communication

\begin{abstract}
Abstrak
Kemunculan virus Covid-19 yang terjadi, memberikan dampak yang cukup besar bagi seluruh dunia, salah satunya adalah negara Indonesia. Dampak Covid-19 dapat dirasakan di berbagai kalangan sektor, termasuk di bidang pendidikan. Maka dari itu, pembelajaran tatap muka bergeser ke pembelajaran daring yang merupakan salah satu konsekuensi logis dari perkembangan teknologi saat ini. Penelitian ini bertujuan untuk menganalisis penerapan strategi komunikasi pada siswa SD Pelita II dalam pembelajaran daring pada masa Covid-19, dengan menggunakan metode studi kasus kualitatif. Model Analisis untuk melihat berbagai permasalahan yang sering ditemui di SD Pelita II dalam pembelajaran daring yang berlangsung. Menggunakan teori difusi inovasi dalam menganalisis permasalahan penelitian ini. Hasil penelitian ini menunjukkan bahwa pelaksanaan pembelajaran daring di SD Pelita II dimulai dari persiapan guru itu sendiri dengan mengajar menggunakan strategi yaitu menciptakan pengertian dan pemikiran yang sama sebagai bentuk dasar komunikasi, proses komunikasi yang terjadi saat pembelajaran daring yaitu disampaikan melalui komunikator (guru) kepada komunikan (siswa).
\end{abstract}

Kata Kunci: covid-19, pembelajaran daring, strategi komunikasi 


\section{Pendahuluan}

Dimulai dengan tahun 2019, dunia digemparkan adanya berita penyakit Corona virus Disease 2019 atau disebut juga dengan istilah virus Covid-19 muncul untuk pertama kali terdeteksi di Wuhan, China (Lesmana, 2021). Infeksi virus tersebut dapat menyerang sistem pernapasan manusia. Virus ini ditemukan dapat menular melalui udara dan mudahnya penyebaran Covid-19 menyebabkan virus tersebut menyebar ke seluruh dunia salah satunya Indonesia.

Menurut dari data yang didapatkan dari Merdeka.com, virus ini muncul pertama kali di Indonesia dengan adanya konfirmasi dari Presiden Jokowi (Winastya, 2021). Dalam menekan kasus penyebaran Covid-19 yang telah tersebar, sejumlah wilayah memutuskan untuk mengadakan yang namanya Pembatasan Sosial Berskala Besar (PSBB) dimulai pertama kali pada tanggal 20 Maret 2020, beberapa wilayah tertentu dibatasi selama kurang lebih dua minggu. Selama penerapan PSBB berlangsung, beberapa kegiatan dibatasi seperti perkantoran, tempat ibadah, dan tempat - tempat umum lainnya ditidiadakan sementara waktu dan digantikan di rumah masing - masing. Salah satunya yaitu Institusi Pendidikan mewajibkan untuk melaksanakan kegiatan secara jarak jauh melalui internet atau daring (Ismawati, 2020).

Mengikuti kata Dimyati (2017) menyatakan pembelajaran dalam jaringan atau yang dikenal dengan istilah e-learning adalah upaya dari penunjangan teknologi dalam mendukung proses belajar mengajar jarak jauh. Dalam penerapan belajar daring, tidak sedikit siswa - siswi yang mengalami kesulitan dalam belajar baik berasal dari diri masing - masing maupun dari luar yang dikenal sebagai faktor internal maupun eksternal. Faktor tersebut dapat dipicu oleh beberapa faktor seperti keterbatasan memiliki gadget, siswa sekolah dasar yang belum mengetahui banyak tentang penggunaan teknologi, kuota yang terbatas dan lainnya. kasus ini sering dijumpai terutama pada sekolah siswa - siswi tingkat TK dan SD (Jamilah, 2020).

Harus diingatkan kembali bahwa aktivitas komunikasi di dalam pelaksanaan pembelajaran kelas merupakan hal yang wajib untuk dapat berkomunikasi secara dua arah atau lebih, Dinamika yang telah disusun dalam pembelajaran daring ini, sebagai penentu perubahan gaya komunikasi belajar di kala pandemi dan dituntut untuk gesit serta imajinatif dalam pengunaan teknologi internet juga merupakan salah satu faktor penting, karena kualitas harus ditingkatkan demi kenyamanan bersama. Perubahan perubahan ini menjadi tantangan baru dan menyebabkan proses komunikasi terhambat, mengingat kembali bahwa setiap individu siswa berbeda - beda dan persiapan yang mendadak untuk dilaksanakan secara cepat.

Peneliti ingin mengangkat topik pembahasan mengenai Pembelajaran daring yang disebabkan karena virus Covid-19, dengan itu tertarik dan ingin menggalih lebih bagaimana proses tersebut terlaksana. Maka dari itu, peneliti memilih salah satu sekolah dasar yaitu SD Pelita II di Jakarta Barat. Penulis bermaksud untuk mengetahui adakah perubahan - perubahan penyusunan strategi komunikasi yang dilakukan oleh subyek penelitian yaitu guru, siswa dan orang tua. 
Tiffany Gintara, Sinta Paramita' Doddy Salman: Analisis Strategi Komunikasi Pembelajaran Daring Siswa Sekolah Pelita II di Masa Covid-19

Gambar 1. Kerangka Pemikiran

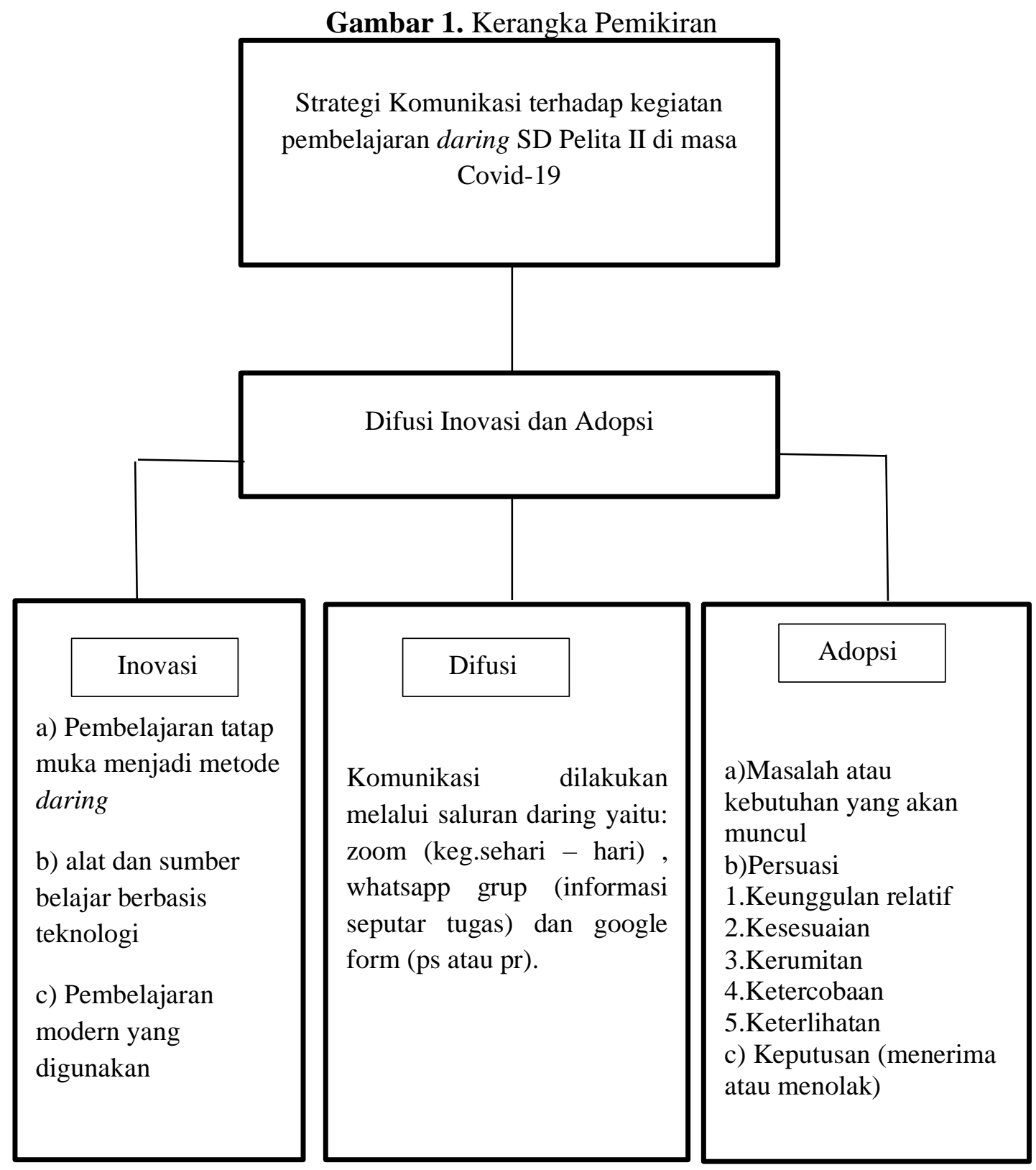

Sumber: Dokumentasi Pribadi

\section{Metode Penelitian}

Penelitian yang dilakukan oleh peneliti dengan metode studi kasus secara rinci dan menggunakan pendekatan kualitatif yang akan dikaitkan dengan isu - isu teoritis tentang peristiwa yang terjadi mengenai pembelajaran daring terhadap Siswa Sekolah Dasar Pelita II di masa Covid-19. Menurut Susilo dan Gudnanto menjelaskan bahwa penelitian studi kasus adalah metode yang diterapkan untuk memahami individu lebih mendalam dengan mempelajari karakter individu yang dipraktekkan secara komprehensif (Sutikno, 2020).

Selanjutnya, subyek dalam penelitian ini terdiri dari guru, siswa dan orangtua sedangkan obyek dalam penelitian ini adalah proses strategi komunikasi pembelajaran daring di SD Pelita II. Hasil data kualitatif akan dibuat menjadi data 
lunak (soft data). Dalam kegiatan pengumpulan data, sumber data menjadi faktor yang penting. Dengan mengetahui data yang baik, sumber data terdapat 2 yaitu Data Primer dan Data Sekunder (Sutikno, 2020), berlandasan teori yang dikumpulkan melalui kata-kata atau kalimat sumber. Dalam penelitian ini peneliti akan menggunakan teknik yang meliputi:

a. Wawancara: Peneliti akan mewawancarkan 3 narasumber yang akan membantu untuk mendapatkan informasi dalam penelitian ini yaitu:

1) Dyah Putri Aryani merupakan guru Bahasa mandarin di SD Pelita II

2) Cheryl Cittadevi Darmawan merupakan siswi kelas 6 di SD Pelita II

3) Marlina merupakan orangtua dari Cheryl SD Pelita II

b. Observasi: Peneliti akan melakukan observasi dan wawancara secara daring terkait kendala yang terjadi di SD Pelita II serta strategi komunikasi yang dilakukan oleh guru itu sendiri.

c. Dokumentasi: Peneliti melakukan kegiatan dokumentasi untuk memperoleh suatu data dalam bentuk informasi serta pengambilan foto ketika melakukan wawancara.

Teknik pengolahan data Menurut Miles dan Huberman dalam proses analisis penelitian kualitatif yaitu reduksi data, penyajian data serta penarikan kesimpulan dan verifikasi, susunan dari informan yang akan diangkat oleh peneliti, hasil penelitian bergantung pada hakikat antara peneliti dengan yang diteliti dan konfirmasi hipotesis akan menjadi lebih baik verifikasinya jika diketahui oleh dua belah pihak secara terbuka sehingga metode ini akan mengumpulkan dan sisi lain mengenai pembelajaran daring di masa pandemi Covid-19.

\section{Hasil Penemuan \& Diskusi}

Mengutip melalui teori difusi inovasi yang dibuat (Rogers) dibalik dasar menunjukkan proses bagaimana suatu inovasi disampaikan dikomunikasikan melalui saluran-saluran tertentu sepanjang waktu kepada sekelompok anggota dari sistem sosial. Hal tersebut sejalan dengan pengertian difusi dari pada dasarnya menjelaskan bahwa terdapat empat elemen penting yaitu :

a. Inovasi: Merupakan gagasan atau ide yang dianggap baru oleh seseorang. (Pembelajaran melalui digital yang dilaksanakan menjadi pembelajaran daring)

b. Anggota sistem sosial: Unit-unit yang berbeda secara fungsional dan terikat dalam kerjasama untuk memecahkan masalah dalam rangka mencapai tujuan bersama. (guru, siswa dan orangtua SD Pelita II)

c. Saluran komunikasi: Saluran untuk menyampaikan pesan atau informasi secara cepat dan efisien inovasi dari sumber kepada penerima. (Aplikasi zoom dan whatsapp)

d. Dimensi waktu: Proses kecepatan keputusan inovasi dari mulai seseorang mengetahui sampai memutuskan untuk menerima atau menolaknya dalam sistem sosial. (Dirumah) 

meliputi:

Adapun lima karakteristik adopsi inovasi yang dikutip melalui Rogers

a. Relative Advantage: Tingkat di mana inovasi dipandang lebih dari yang digantikan, keuntungan - keuntungan meliputi teknis, ekonomis dan kemanfaatan sosial psikologis. Menurut key informan 3 bahwa sekarang dalam bidang pengetahuan memotivasi anak lebih semangat belajar, karena serba instan. Penting bagi proses keputusan inovasi dibuat dengan benar salah satunya yah pembelajaran daring ini.

b. Compability: Bahwa tingkat nilai - nilai inovasi dianggap konsisten dan mempunyai nilai yang ada dari pengalaman sebelumnya dan kebutuhan mendatang. Dalam hal tersebut tentunya Sebuah inovasi pada zaman teknologi sekarang ini, lebih memudahkan siswa dalam mendapatkan sesuatu dengan waktu yang singkat, menurut key informan 1 mengurangi metode pembelajaran yang konvensional melainkan lebih fokus terhadap pembelajaran modern yang dimana kita sebagai guru harus mengikuti perkembangan tersebut juga.

c. Complexity: Konsep ini menunjukkan bahwa apakah tingkat inovasi tersebut rumit bagi individu - individu. Menurut key informan 1 Bagaimana cara mengkomunikasikan materi - materi kepada siswa SD Pelita II (komunikan) sangatlah berpengaruh, manakala cukup sederhana saya selalu membuat Bahasa mudah untuk dipahami.

d. Triability: kadar dalam adopsi difusi dan inovatif akan semampai apabila pihak konsumen merasakan adanya kemajuan yang dirasakan terutama untuk mencoba lebih dulu apakah produk tersebut memang pantas untuk dipakai. Menurut key informan 1 Sudah dibuktikan sendiri seperti contoh di bawah bahwa murid lebih senang belajar dengan PPT (Power Point), disini saya juga kebanyakan sekarang menggunakan gambar atau animasi terutama apda siswa sekolah dasar.

e. Observability: Keterlihatan atau keahlian untuk dipahami suatu hasil inovasi dapat dilihat oleh khalayak. Dalam hal tersebut di wawancara bersangkutan yaitu; Menurut Key informan 2 bahwa belajar dengan PPT (Power Point) dan dibuat dalam bentuk materi lebih mudah dari pada di buku, karena lebih langsung ke intinya dan tidak terlalu panjang.

Hasil data observasi, wawancara dan dokumentasi yang telah dilaksanakan di SD Pelita II menyatakan bahwa awal pembelajaran daring berlangsung pada tanggal 18 Maret 2020 - 18 Mei 2020 dalam periode waktu 3 bulan cenderung naik dan mendukung. Proses strategi komunikasi yang dimana pada awalnya cukup menyulitkan bagi pihak guru, siswa dan orangtua di awal, tetapi karena sering dilakukan evaluasi bersama serta dukungan yang baik dari pihak sekolah dapat terlihat dari hasil observasi seiring bertambahnya waktu terlihat bahwa proses komunikasi yang terjadi mengalami peningkatan.

Dalam pelaksanaan pembelajaran daring dimana menggunakan media daring sebagai alat penyaluran informasi berupa aplikasi "zoom" untuk mengadakan rapat pembelajaran daring dan "whatsapp grup" dalam memberikan pesan atau informasi sehari-harinya secara terbuka. Selain itu, Hasil penelitian ini menunjukkan bahwa pelaksanaan pembelajaran online di SD Pelita II dimulai dari persiapan guru itu sendiri dengan mengajar menggunakan strategi yaitu menciptakan pengertian dan pemikiran yang sama sebagai bentuk dasar komunikasi., melalui proses komunikasi 
yang terjadi saat pembelajaran daring yaitu disampaikan melalui komunikator (guru) kepada komunikan (siswa).

\section{Simpulan}

Berdasarkan hasil analisis yang diperoleh menggunakan teori difusi inovasi mengenai analisis strategi komunikasi pembelajaran daring di SD Pelita II di masa Covid-19, maka peneliti menyimpulkan bahwa strategi komunikasi diantara tiga pihak yaitu guru, siswa dan orangtua secara umum cenderung baik dan mendukung. Dalam pelaksanaan pembelajaran daring dimana menggunakan media daring sebagai alat penyaluran informasi berupa aplikasi "zoom" untuk mengadakan rapat pembelajaran daring dan "whatsapp grup" dalam memberikan pesan atau informasi sehari-harinya secara terbuka.

Selain itu, bentuk strategi komunikasi yang dilakukan di SD Pelita II yaitu ditentukan dengan pengaruh besar dari peran guru dalam menyampaikan materi materi baik verbal maupun non verbal yang tersalurkan kepada siswa dan tidak lupa peran penting dari orangtua di rumah yang ikut serta untuk menyampaikan kesulitan yang dihadapi oleh anak mengenai materi - materi sekolah sekaligus kondisi fisik dan psikologis anak. Hasil penelitian ini menunjukkan bahwa pelaksanaan pembelajaran daring di SD Pelita II dimulai dari persiapan guru itu sendiri dengan mengajar menggunakan strategi yaitu menciptakan pengertian dan pemikiran yang sama sebagai bentuk dasar komunikasi. Selain itu, proses komunikasi yang terjadi saat pembelajaran daring yaitu disampaikan melalui komunikator (guru) kepada komunikan (siswa).

\section{Ucapan Terima Kasih}

Peneliti ingin mengucapkan terima kasih kepada Fakultas Ilmu Komunikasi Universitas Tarumanagara, narasumber, serta semua pihak yang turut membantu peneliti sehingga penelitian ini dapat diselesaikan.

\section{Daftar Pustaka}

Aden Fani Rahmasari, Setiawan, F., \& Meirza Nanda Faradita. (2020). Pengaruh Pembelajaran Online Terhadap Kemandirian Belajar Siswa Kelas II SD Muhammadiyah 17 Surabaya di Tengah Pandemi Covid-19. INVENTA, 4(2). https://doi.org/10.36456/inventa.4.2.a2609

Ambar, R. (2021). Komunikasi Pemasaran UMKM dalam Beradaptasi di Masa Pandemi Covid-19 (Studi Kasus Hello Cafe). https://journal.untar.ac.id/index.php/prologia/article/view/10107

Handayani, S., Masfuah, S., \& Kironoratri, L. (2021). Analisis Kemampuan Komunikasi Siswa dalam Pembelajaran Daring Siswa Sekolah Dasar. Edukatif: Jurnal Ilmu Pendidikan, 3(5), 2240-2246. https://www.edukatif.org/index.php/edukatif/article/view/770

Ismawati, D., \& Prasetyo, I. (2020). Efektivitas Pembelajaran Menggunakan Video Zoom Cloud Meeting pada Anak Usia Dini Era Pandemi Covid-19. Jurnal Obsesi: Jurnal Pendidikan Anak Usia Dini, 5(1), 665. https://doi.org/10.31004/obsesi.v5i1.671

Jamilah. (2020). Dampak Pembelajaran Daring di Tengah Pandemi COVID 19 pada 
Tiffany Gintara, Sinta Paramita' Doddy Salman: Analisis Strategi Komunikasi Pembelajaran Daring Siswa Sekolah Pelita II di Masa Covid-19

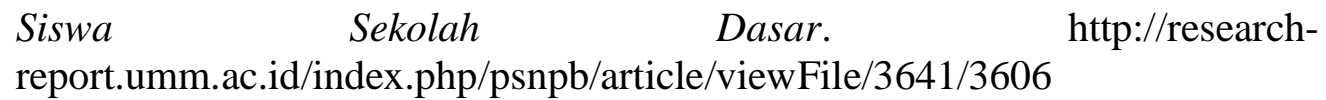

Sutikno, S. (2020). Pendekatan Kualitatif (Nurlaeli (ed.)). Prosmala Hadisaputra. 